Brook, R. W., L. A. Pollock, K. F. Abraham, and G. S. Brown. 2021. Bird trends from long-term observation data at sites in the Hudson Bay Lowlands. Avian Conservation and Ecology 16(1):10. https://doi.org/10.5751/ACE-01821-160110

Copyright (C) 2021 by the author(s). Published here under license by the Resilience Alliance.

Research Paper

\title{
Bird trends from long-term observation data at sites in the Hudson Bay Lowlands
}

\author{
Rodney W. Brook ${ }^{1}$, Lisa A. Pollock ${ }^{1}$, Kenneth F. Abraham ${ }^{1}$ and Glen S. Brown ${ }^{1}$ \\ ${ }^{1}$ Ontario Ministry of Natural Resources and Forestry
}

\begin{abstract}
Monitoring population trends for bird species in the Arctic and sub-Arctic can be difficult and cost prohibitive. Breeding populations of birds in these remote locations may be changing and have garnered much attention regarding their conservation. We analyzed data from bird lists (daily species observations) collected while conducting other targeted research to estimate trends in the probability of observing species at two sub-Arctic study sites. For Akimiski Island, Nunavut (52 species) we estimated positive trends with high confidence ( $95 \%$ credible limits do not include 0 ) for 14 species and negative trends with high confidence for 18 . For Burntpoint Creek, Ontario (46 species) we estimated that 12 species had positive trends with high confidence and 12 had negative trends with high confidence. More than $60 \%$ of species at each site matched population trends for at least one of three larger geographic scales that we compared estimates with; regional, provincial and national. We hypothesized that trends may be due to climate change effects or because of effects related to intensive herbivory from nesting geese. Trends for most of the species where we made specific predictions from these hypotheses agreed with those predicted; however, well-designed experiments are needed to conclusively determine the driving mechanisms of these trends. Collecting bird list data while simultaneously conducting other research is not nearly as time consuming or expensive as targeted breeding bird surveys (e.g., point counts, call counts, nest searching, etc.). This analysis method may be of utility for other remote field study sites where gaps in trend data exist.
\end{abstract}

\section{Tendances des oiseaux à partir d'observations faites depuis longtemps sur des sites dans les basses- terres de la baie d'Hudson}

RÉSUMÉ. Le suivi de la tendance des populations d'oiseaux dans l'Arctique et le subarctique peut être difficile et son coût prohibitif. Les populations d'oiseaux nicheurs dans ces endroits éloignés sont peut-être en train de changer et leur conservation a suscité beaucoup d'attention. Nous avons analysé les données de listes d'oiseaux (observations quotidiennes d'espèces) recueillies lors d'autres recherches ciblées afin d'estimer la tendance de la probabilité d'observer des espèces à deux sites d'étude subarctiques. Pour l'île Akimiski, au Nunavut (52 espèces), nous avons calculé des tendances positives avec un niveau de confiance élevé (les limites crédibles à $95 \%$ ne comprennent pas les 0 ) pour 14 espèces et des tendances négatives avec un niveau de confiance élevé pour 18 autres. Pour le ruisseau Burntpoint, en Ontario (46 espèces), nous avons déterminé que 12 espèces présentaient des tendances positives avec un niveau de confiance élevé et 12 des tendances négatives avec un niveau de confiance élevé. La tendance de plus de $60 \%$ des espèces à chaque site correspondait aux tendances de populations d'au moins une des trois grandes échelles géographiques avec lesquelles nous avons comparé les résultats : régionale, provinciale et nationale. Nous avons émis l'hypothèse selon laquelle les tendances pouvaient être imputables aux effets du changement climatique ou aux effets liés au broutement intensif des oies nicheuses. Les tendances pour la plupart des espèces pour lesquelles nous avons fait des prédictions spécifiques à partir de ces hypothèses corroboraient celles prédites; toutefois, des protocoles expérimentaux bien conçus sont nécessaires pour déterminer de manière concluante les mécanismes moteurs de ces tendances. La collecte d'observations au moyen de listes d'oiseaux, tout en menant simultanément d'autres recherches, est loin d'être aussi longue et coûteuse que les suivis ciblés d'oiseaux nicheurs (p. ex. dénombrement par points d'écoute, relevé de chants, recherche de nids, etc.). Cette méthode d'analyse peut être utile pour d'autres sites d'étude éloignés où les tendances sont inconnues.

Key Words: Bayesian logistic model; climate change; overgrazing; habitat change; list length; population trends

\section{INTRODUCTION}

Monitoring of population trends for bird species occurs through several government and non-government sponsored programs and at multiple spatial scales in North America (e.g., ECCC 2019, Sauer et al. 2004). Available evidence indicates that populations of most waterfowl species have increased and those of most shorebird species have declined (Rosenberg et al. 2019, Smith et al. 2020). Populations of most landbird species have been mostly stable but some have declined in recent decades, with some showing large declines (NABCI Canada 2019, Rosenberg et al. 2019, Smith et al. 2020).

Population indices from the breeding range are preferred for informing management and conservation as observations during migration (Ross et al. 2012) or on wintering ranges (Newbold et al. 2012) may reflect a mixture of animals from reproductively isolated populations. Indices from winter range counts may also be subject to overdispersion issues (Richards 2007) due to 
clumping and bias from uneven distribution and survey coverage. Species whose breeding ranges are not easily accessed are generally not well monitored, particularly in more northerly regions (ECCC 2018, Roy et al. 2019). Exceptions may include species that are the target of research or game species whose numbers are monitored for harvest management purposes, (e.g., Canada Geese (Branta canadensis): Leafloor et al. 1996 and Snow Geese (Anser caerulescens): Kerbes et al. 2014). Other programs provide long-term datasets but may not have enough geographic coverage to adequately survey all species breeding ranges (e.g., Sauer et al. 2013). Citizen science-based programs and incidental observations have proven to contribute valuable knowledge for tracking status and trends in populations, especially where standardized surveys or management-driven monitoring programs are lacking (Crewe et al. 2008, Bonter and Cooper 2012, Callaghan and Gawlik 2015, Walker and Taylor 2017). However, these programs rarely target those breeding populations that are in difficult to access areas such as the Arctic and sub-Arctic where status of breeding birds has received increasing management and conservation attention.

For species in decline, population change may be driven by factors on the breeding range, during migration, and in wintering areas. The drivers of change may manifest through negative impacts on juvenile and adult survival or through impacting reproductive success and recruitment. In Arctic and sub-Arctic regions, bird population change may be occurring through the direct or indirect effects of climate change (Butler 2000, Ims et al. 2019). Similarly, herbivory by overabundant geese (Abraham and Jefferies 1997, Flemming et al. 2016, Buij et al. 2017, Flemming et al. 2019) may also be causing bird population change due to the change these herbivores induce on their habitat. These two phenomena may independently cause change in bird populations in this region or they may interact resulting in little habitat change (Post 2013, Biuw et al. 2014) or in compounded change. Climate change effects are predicted to be most pronounced at higher latitudes (ACIA 2005) and are expected to impact the sub-Arctic and Arctic regions first (IPCC 2018). Habitat change in these regions has been observed including the encroachment of shrubs in tundra habitats (Post et al. 2019), drying of wetland habitats (Roach et al. 2011), or mismatch for some species between the timing of hatch and the availability of their primary food sources for young (McKinnon et al. 2012, Brook et al. 2015). Further, most Arctic and sub-Arctic breeding birds occupy intermediate trophic levels and may be more vulnerable to climate change effects than species at other trophic levels because they may be subjected to both topdown and bottom-up ecological change (Weiser et al. 2018a). There is evidence that Arctic breeding shorebirds are exhibiting declines worldwide (Studds et al. 2017, Weiser et al. 2020) and opportunities to enhance monitoring and trend assessments are needed to inform conservation.

Here we used list analyses methods (Roberts et al. 2017, Szabo et al. 2010) to estimate change in long-term (17 to 23 years) bird list datasets for species at two sub-Arctic study sites. We only included species where we deemed observation effort was consistent through time to ensure that survey methods did not result in the detection of false trends. We hypothesized that any speciesspecific trends we detected would be consistent with trends reported from larger geographic scale assessments for those species. Trends that did not match those from larger scale assessments may be due to more localized drivers at each study site; drivers that are not widespread or acting at the larger geographic scales. We hypothesized that habitat damage due to localized herbivory at the more southerly study site (Kotanen and Abraham 2013) could potentially compound the broader scale environmental impacts on habitat that could be driving some of the trends we observed. Further, we predicted that the presence of herbivores (Canada and Lesser Snow Geese) attracts both avian (American Crow (Corvus brachyrhynchos), Common Raven (Corvus corax)) and mammalian predators that may increase predation of eggs for other species, especially breeding ducks (Mallard (Anas platyrhynchos), American Black Duck ( $A$. rubripes), Northern Pintail (A. acuta), and Green-winged Teal ( $A$. crecca)) and breeding shorebirds (Semipalmated plover (Charadrius semipalmatus), Short-billed Dowitcher (Limnodromus griseus), and Least Sandpiper (Calidrus minutilla) thus causing negative trends for those species. We also predicted that, through encroachment of shrubs in open graminoid areas at the more northerly site (predominantly low-tundra habitat), species that would benefit from increasing shrub habitat would likely increase, including American Tree Sparrow (Spizella arborea), Lincoln's Sparrow (Melospiza lincolnii), Song Sparrow (M. melodia), and White-throated Sparrow (Zonotrichia albicollis).

\section{METHODS}

Daily observations of all bird species were performed at Akimiski Island, Nunavut (N53.013, W81.321) from 1993 to 2015 (N = 23 yr) and at Burntpoint Creek, Ontario (N55.241, W84.318) from 2001 to 2005 and 2007 to 2018 ( $\mathrm{N}=17 \mathrm{yr}$ ). Although data were collected for variable periods annually, observations used in analysis were restricted to those between 21 May and 4 August at both locations.

Observations were done by researchers (from 4 to 20 per day) with varying bird identification experience (from minimal to advanced) while performing fieldwork on long-term Canada Goose, Lesser Snow Goose (Leafloor et al. 2000), and shorebird research projects (Nguyen et al. 2003, Pollock et al. 2012, Weiser et al. 2020). While in the field, observers recorded all bird species encountered by sight and sound, according to their abilities. At the end of each day, a composite list of bird observations was compiled from all observers.

We restricted data to include those species known to be within their breeding range based on available literature and documented evidence or where we had confirmation of breeding evidence at our local sites (Cadman et al. 2007, MNRF unpublished data). We excluded locally non-breeding and transient species that often occurred at our sites (e.g., Black-bellied Plover (Pluvialis squatarola)) but whose presence and abundance in any year may be affected more by weather than true population change. To reduce the potential effect of bias on trends, we also removed species observed in less than $20 \%$ of years and on less than $3 \%$ of observation days because of known issues with trend analysis. Szabo et al. (2010) found that rare species were reported at a rate unaccounted for by list length. Thus, we assumed that observations of these rare species as we defined them were likely more by chance than associated with effort and change over time. Some species that were the focus of intense research were also excluded due to the potential for a false trend because of increased observation effort for a limited number of years during the time 
series; however, we did model one such species, Smith's Longspur (Calcarius pictus) at Burntpoint Creek, but excluded a single year (2007) when a Smith's Longspur project had occurred. We also removed extremely abundant species (observed $>85 \%$ of observation days in each year) as any survey (day) without an observation was likely an anomaly due to lack of field work in a portion of the study area on that day (e.g., Lesser Snow Goose, where the colony was not visited daily). This would not necessarily result in a bias; however, we would still not likely be able to reliably detect a trend for these very abundant species. Species that bred in habitats not consistently surveyed (e.g., inland sedge meadows on Akimiski Island) were also excluded because of the same potential for false trends resulting from inconsistent surveying. The result of our exclusions and restrictions is a subset of species for which we have highest confidence in consistency of status (e.g., breeding) and observation effort (e.g., unbiased by numerical abundance or from increased detection by targeted research).

The geographic area covered at each site (proportion of typical study area) varied daily but was similar between years. We used a list length analysis to compensate for effort differences, which assumes the number of species (list length) observed in each survey (in our case, a day) increases with increasing effort (see Szabo et al. 2010). This also compensated for observer skill as we equated longer lists with observers with greater bird identification experience. Logistic regression was used to model the probability of a species presence as a function of the total number of species (the list length) and year surveyed (Link et al. 2006, Szabo et al. 2010). We assessed three additive trend models (all included a year effect): 1) a prevalence model (intercept + year), 2) an effort model (intercept + year $+\log ($ list length)), and 3 ) a date/effort model (intercept + year $+\log ($ list length $)+$ day of year). Species detection probability may be density dependent which is a known potential complication for this method (Szabo et al. 2010); however, the mix of skills and number of observers contributing to daily lists mediates potential bias due to detection rate change. We included a model with day of year to account for any seasonal differences there might be for species detection probability (Walker and Taylor 2017). For each species, we estimated parameter coefficients for the three models in a Bayesian logistic model regression framework.

We fitted models using Markov Chain Monte Carlo (MCMC) simulation using uninformed priors (mean of 0 and standard deviation of 10000) with 80000 iterations and 20000 burn-in iterations and a thinning rate of five. As in Szabo et al. (2010), input variables were centered with a mean of 0 but were not rescaled to units of standard deviation to help with interpretation. We implemented JAGS 4.3.0 (Gelfand and Smith 1990, Plummer 2013) from program R (R Development Core Team 2018) using the package jagsUI (Kellner 2018). To determine whether each species models converged, we calculated Geweke z-scores (Geweke 1992) for each coefficient using $R$ package ggmcmc (Fernández-iMarín 2020) and also inspected plots of their traces. Any parameter coefficient with a Geweke z-score greater than 2.0 or less than -2.0 for any of three chains was deemed to have poor convergence and models were run again until there was acceptable convergence. We made further convergence assessment using the Gelman-Rubin diagnostic R (Gelman et al. 2004). Convergence was achieved for parameters (all $\mathrm{R}<1.1$ ) using three chains. For each species, we evaluated model fit by measuring the deviance from the null model that was explained by the fitted model using Deviance Information Criterion (DIC: Spiegelhalter et al. 2002). Models with $\Delta \mathrm{DIC}<2$ have similar strong support and we used the rules of parsimony to select models from which to make an inference. We present the results for the year effect regardless of whether the 95\% credible limits included zero (a low confidence trend) and categorized trends where $95 \%$ credible limits did not include zero as a high confidence trend.

We compared our trend estimates (probability of observing each species) for each study site with trends from larger geographic scales. We directly compared our estimates of trend with those for the Hudson Bay Lowlands (which encompasses both study sites) reported in the second breeding bird atlas of Ontario (Cadman et al. 2007). In the second Ontario breeding bird atlas, probability of observation was compared between the first (1981-1985) and second (2001-2005) atlases and statistical significance $(\mathrm{P}<0.1)$ of change was reported (Cadman et al. 2007). At the Ontario provincial scale, we compared our results with abundance trends estimated from an analysis of the Breeding Bird Survey of North America (Smith and Edwards 2020). We used custom trends calculated from the annual Canadian Wildlife Service analyses of the Breeding Bird Survey (Smith et al. 2020) for time intervals matching those for our trends from each study area. At the national scale, we used abundance trends from the Breeding Bird Survey of North America (Smith et al. 2020) also estimated for the same time periods as for each study area. In all cases, if the credible limit included zero for the year effect, we had little confidence in the estimated trend (a low confidence trend). To assess the consistency of trends between study sites and among scales, we estimated the correlation using a Pearson correlation including 95\% confidence limits (significance was determined at alpha $<0.05)$.

\section{RESULTS}

In total, 811 and 342 surveys (survey-days) were used for analysis for Akimiski Island and Burntpoint Creek, respectively. After screening species due to rarity, inconsistent surveying, outside of breeding range, and super abundance, we found the trend model (estimating list length and year effects) or the day model (estimating list length, day of year and year effects) to be the most parsimonious for most species. We compared trend (year effect covariate) results for 52 species observed at Akimiski Island (Fig. 1, Table 1) and 46 at the Burntpoint Creek study area (Fig. 2, Table 2). For Akimiski Island, we found 32 species with trends that did not include 0 within the $95 \%$ credible limits; 14 positive and 18 negative. For Burntpoint Creek, we found 24 species with trends that did not include 0 within the $95 \%$ credible limits; 12 positive and 12 negative. We identified trends for $33(63.5 \%)$ and $31(67.4 \%)$ species for Akimiski Island and Burntpoint Creek, respectively, that matched the direction of trends for at least one of the three larger geographic scales. Conversely, $19(36.5 \%)$ species observed at Akimiski Island and 15 (32.6\%) for the Burntpoint Creek study area (three in common) did not match the direction of trends for at least one of three larger geographic scales. There was a positive but insignificant correlation $(0.20$, $95 \% \mathrm{CL}=-0.182$ to $0.526, \mathrm{P}=0.31$ ) between trends for species common to both study areas $(\mathrm{N}=29$, Figure 3$)$; however, where there were high confident trends for species in common at both sites $(\mathrm{N}=10)$, five species had the same trend direction (American 
Avian Conservation and Ecology 16(1): 10

Table 1. Mean trends of the probability of observation (and 95\% credible limits) estimated from daily bird count data for species surveyed annually at the Akimiski Island study site in the sub-Arctic, 1993 to 2015. Trend comparisons are with those at the 1) regional scale; the Hudson Bay Lowlands (HBL) Breeding Bird Atlas trend from estimating the probability of observation between the first (1981 to 1985) and second (2001 to 2005) Atlases in Ontario, the 2) provincial scale using trends in abundance from the North American Breeding Bird Survey (1993 to 2015) and with the 3) Breeding Bird Survey at the national scale (1993 to 2015).

\begin{tabular}{|c|c|c|c|c|c|}
\hline ORDER and common name & Scientific name & Akimiski Island & $\begin{array}{c}\mathrm{HBL}^{\dagger} \\
\text { Atlas }^{\dagger}\end{array}$ & Ontario $\mathrm{BBS}^{t}$ & Canada $\mathrm{BBS}^{\S}$ \\
\hline \multicolumn{6}{|l|}{ ANSERIFORMES } \\
\hline Mallard & Anas platyrhynchos & $0.072(0.031-0.113)^{*}$ & No trend & -0.414 & -0.365 \\
\hline American Black Duck & Anas rubripes & $0.004(-0.029-0.037)$ & No trend & $-4.994 *$ & -2.634 \\
\hline Northern Shoveler & Spatula clypeata & $0.007(-0.035-0.049)$ & No trend & & \\
\hline Northern Pintail & Anas acuta & $-0.028(-0.068-0.013)$ & No trend & -4.298 & -0.953 \\
\hline Green-winged Teal & Anas crecca & $-0.101(-0.141-0.061)^{*}$ & No trend & -1.374 & 0.12 \\
\hline American Wigeon & Mareca americana & $-0.126(-0.177-0.077)^{*}$ & No trend & -1.766 & 0.298 \\
\hline Common Merganser & Mergus merganser & $-0.027(-0.069-0.016)$ & No trend & -0.05 & -2.126 \\
\hline Red-breasted Merganser & Mergus serrator & $-0.03(-0.079-0.019)$ & No trend & $-3.555^{*}$ & -3.343 \\
\hline Hooded Merganser & Lophodytes cucullatus & $-0.015(-0.097-0.069)$ & No trend & $3.255^{*}$ & $2.994 *$ \\
\hline \multicolumn{6}{|l|}{ GAVIIFORMES } \\
\hline Pacific Loon & Gavia pacifica & $-0.194(-0.282-0.11)^{*}$ & No trend & & \\
\hline Common Loon & Gavia immer & $0.045(0.013-0.078)^{*}$ & No trend & -0.408 & 0.694 \\
\hline \multicolumn{6}{|l|}{ PELECANIFORMES } \\
\hline American Bittern & Botaurus lentiginosus & $0.032(-0.006-0.071)$ & No trend & -0.546 & 0.746 \\
\hline \multicolumn{6}{|l|}{ ACCIPITRIFORMES } \\
\hline Northern Harrier & Circus hudsonius & $0.076(0.041-0.11)^{*}$ & Increase & $-2.187 *$ & $-2.326^{*}$ \\
\hline \multicolumn{6}{|l|}{ STRIGIFORMES } \\
\hline Short-eared Owl & Asio flammeus & $0.072(0.029-0.115)^{*}$ & Increase & & \\
\hline \multicolumn{6}{|l|}{ GRUIFORMES } \\
\hline Sandhill Crane & Antigone canadensis & $0.065(0.032-0.098)^{*}$ & Increase & $11.044^{*}$ & $6.182 *$ \\
\hline \multicolumn{6}{|l|}{ CHARADRIIFORMES } \\
\hline Killdeer & Charadrius vociferous & $0.083(0.041-0.127)^{*}$ & Increase & $-4.433 *$ & $-2.202 *$ \\
\hline Semipalmated Plover & Charadrius semipalmatus & $-0.093(-0.133--0.053)^{*}$ & No trend & & \\
\hline Greater Yellowlegs & Tringa melanoleuca & $0.152(0.112-0.194)^{*}$ & Increase & 0.645 & 0.997 \\
\hline Lesser Yellowlegs & Tringa flavipes & $0.008(-0.027-0.043)$ & No trend & & \\
\hline Hudsonian Godwit & Limosa haemastica & $-0.067(-0.102-0.032)^{*}$ & No trend & & \\
\hline Marbled Godwit & Limosa fedoa & $-0.022(-0.061-0.015)$ & No trend & & \\
\hline Least Sandpiper & Calidris minutilla & $-0.047(-0.083--0.012)^{*}$ & No trend & & \\
\hline Short-billed Dowitcher & Limnodromus griseus & $-0.045(-0.087-0.002)^{*}$ & No trend & & \\
\hline Wilson's Snipe & Gallinago delicata & $-0.064(-0.101-0.027)^{*}$ & Increase & -0.494 & 0.938 \\
\hline Bonaparte's Gull & Chroicocephalus philadelphia & $-0.089(-0.126-0.052) *$ & No trend & 0.995 & -1.874 \\
\hline Arctic Tern & Sterna paradisaea & $-0.052(-0.086-0.018)^{*}$ & No trend & & \\
\hline Caspian Tern & Hydroprogne caspia & $0.041(-0.037-0.121)$ & No trend & 0.052 & -0.325 \\
\hline \multicolumn{6}{|l|}{ PICIFORMES } \\
\hline Northern Flicker & Colaptes auratus & $-0.054(-0.089-0.019)^{*}$ & Increase & -0.43 & $-1.033^{*}$ \\
\hline \multicolumn{6}{|l|}{ PASSERIFORMES } \\
\hline Alder Flycatcher & Empidonax alnorum & $0.19(0.119-0.267)^{*}$ & Increase & -0.556 & -0.69 \\
\hline Canada Jay & Perisoreus canadensis & $0.042(0.002-0.083)^{*}$ & Increase & 0.753 & -0.257 \\
\hline Common Raven & Corvus corax & $0.054(0.017-0.092)^{*}$ & Increase & -0.854 & $0.892 *$ \\
\hline American Crow & Corvus brachyrhynchos & $0.238(0.195-0.283)^{*}$ & Increase & 0.161 & $-0.311 *$ \\
\hline Horned Lark & Eremophila alpestris & $-0.143(-0.184-0.103)^{*}$ & No trend & $-5.093 *$ & $-4.731^{*}$ \\
\hline Boreal Chickadee & Poecile hudsonicus & $-0.072(-0.136-0.007)^{*}$ & No trend & -0.789 & -0.454 \\
\hline Ruby-crowned Kinglet & Regulus calendula & $0.052(-0.002-0.107)$ & Increase & 0.572 & $1.582 *$ \\
\hline Hermit Thrush & Catharus guttatus & $0.034(0.002-0.066)^{*}$ & Increase & 0.446 & -1.184 \\
\hline American Robin & Turdus migratorius & $0.004(-0.032-0.04)$ & Increase & $-1.417^{*}$ & $-0.456^{*}$ \\
\hline Tennessee Warbler & Leiothlypis peregrina & $0.021(-0.022-0.064)$ & No trend & $-7.476^{*}$ & -1.136 \\
\hline Orange-crowned Warbler & Leiothlypis celata & $0.018(-0.04-0.077)$ & Increase & 0.692 & $-1.593^{*}$ \\
\hline Yellow Warbler & Setophaga petechia & $0.019(-0.013-0.052)$ & Increase & $-2.189 *$ & $-1.047 *$ \\
\hline Yellow-rumped Warbler & Setophaga coronata & $0.005(-0.035-0.045)$ & Increase & -0.386 & -0.868 \\
\hline Wilson's Warbler & Cardellina pusilla & $0.055(-0.04-0.155)$ & Increase & 0.135 & 0.281 \\
\hline American Tree Sparrow & Spizelloides arborea & $-0.129(-0.196-0.063)^{*}$ & No trend & & \\
\hline LeConte's Sparrow & Ammospiza leconteii & $0.08(-0.021-0.186)$ & Increase & $-3.497 *$ & $-3.749^{*}$ \\
\hline Savannah Sparrow & Passerculus sandwichensis & $-0.047(-0.092-0.002) *$ & Increase & $-3.253 *$ & $-1.412 *$ \\
\hline Fox Sparrow & Passerella iliaca & $-0.002(-0.038-0.033)$ & Increase & -1.973 & 0.254 \\
\hline Lincoln's Sparrow & Melospiza lincolnii & $-0.053(-0.09-0.017)^{*}$ & Increase & $-1.935^{*}$ & -1.176 \\
\hline Swamp Sparrow & Melospiza georgiana & $-0.064(-0.113-0.016)^{*}$ & Increase & $1.725^{*}$ & 0.538 \\
\hline Song Sparrow & Melospiza melodia & $0.087(0.004-0.172)^{*}$ & Increase & $-0.892 *$ & $-0.534 *$ \\
\hline White-crowned Sparrow & Zonotrichia leucophrys & $0.103(0.066-0.142)^{*}$ & Increase & & \\
\hline Dark-eyed Junco & Junco hyemalis & $-0.008(-0.042-0.027)$ & Increase & -1.769 & -0.667 \\
\hline Common Redpoll & Acanthis flammea & $-0.12(-0.162-0.08)^{*}$ & No trend & -2.029 & -1.743 \\
\hline
\end{tabular}

Regional scale Hudson Bay Lowlands trends from the Ontario Breeding Bird Atlas (Cadman et al. 2007)

"Ontario provincial scale trends from the North American Breeding Bird Survey for the time period 1993 to 2015 (Smith and Edwards 2020)

${ }^{8}$ Canada national scale trends from the North American Breeding Bird Survey for the time period 1993 to 2015 (Smith and Edwards 2020)

*Indicates a species had a trend where zero was not within the $95 \%$ credible limits 
Fig. 1. Mean coefficients for the effect of year (trend) on the probability of observation for bird species at the Akimiski Island, Nunavut study site based on daily bird count data from 1993 to 2015 . Values are logit-transformed probability of observation and bars are $95 \%$ credible limits.

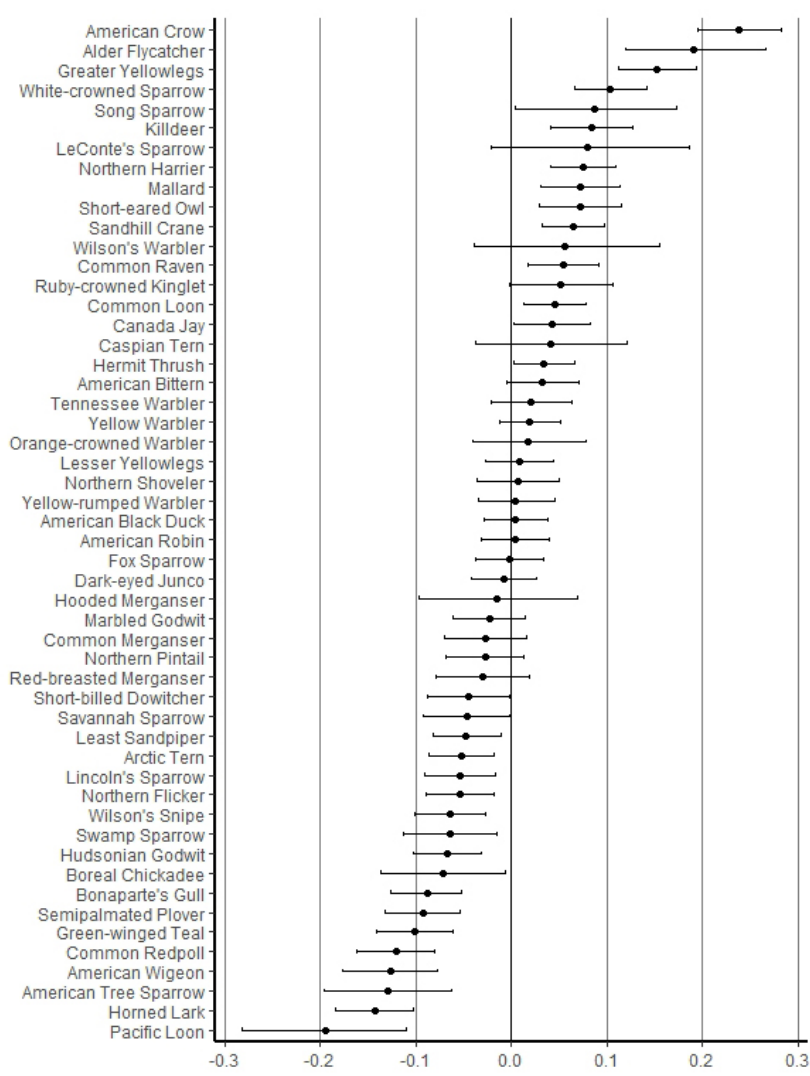

Tree Sparrow, Pacific Loon (Gavia pacifica), Sandhill Crane (Antigone canadensis), Semipalmated Plover, and Song Sparrow) and five had opposite trend directions (Killdeer (C. vociferous), Least Sandpiper, Mallard, Short Eared Owl (Asio flammeus) and Swamp Sparrow (M. georgiana)). There were also positive but insignificant correlations between Akimiski Island and the provincial Breeding Bird Survey trends $(0.19,95 \% \mathrm{CL}=-0.128$ to $0.474, \mathrm{P}=0.24)$ and the national Breeding Bird Survey trends $(0.17,95 \% \mathrm{CL}=-0.114$ to $0.428, \mathrm{P}=0.24)$ (Figure 4). Similarly, there were positive but insignificant correlations between Burntpoint Creek and the provincial Breeding Bird Survey trends $(0.16,95 \% \mathrm{CL}=-0.249$ to $0.524 \mathrm{P}=0.44)$ and the national Breeding Bird Survey trends $(0.004,95 \% \mathrm{CL}=-0.308$ to $0.314, \mathrm{P}$ $=0.98)$.

\section{DISCUSSION}

The trend that we observed for most species matched that reported for at least one of the larger geographic scales (i.e., region, provincial or national) suggesting that the processes causing most trends that we detected at a study site scale might be part of trends occurring at the larger scales or the cause may occur outside the breeding seasons (i.e., during migration or on wintering areas for
Fig. 2. Mean coefficients for the effect of year (trend) on the probability of observation for bird species trends at the Burntpoint Creek, Ontario study site based on daily bird count data from 2001 to 2018 (excluding 2006). Values are logittransformed probability of observation and bars are $95 \%$ credible limits.

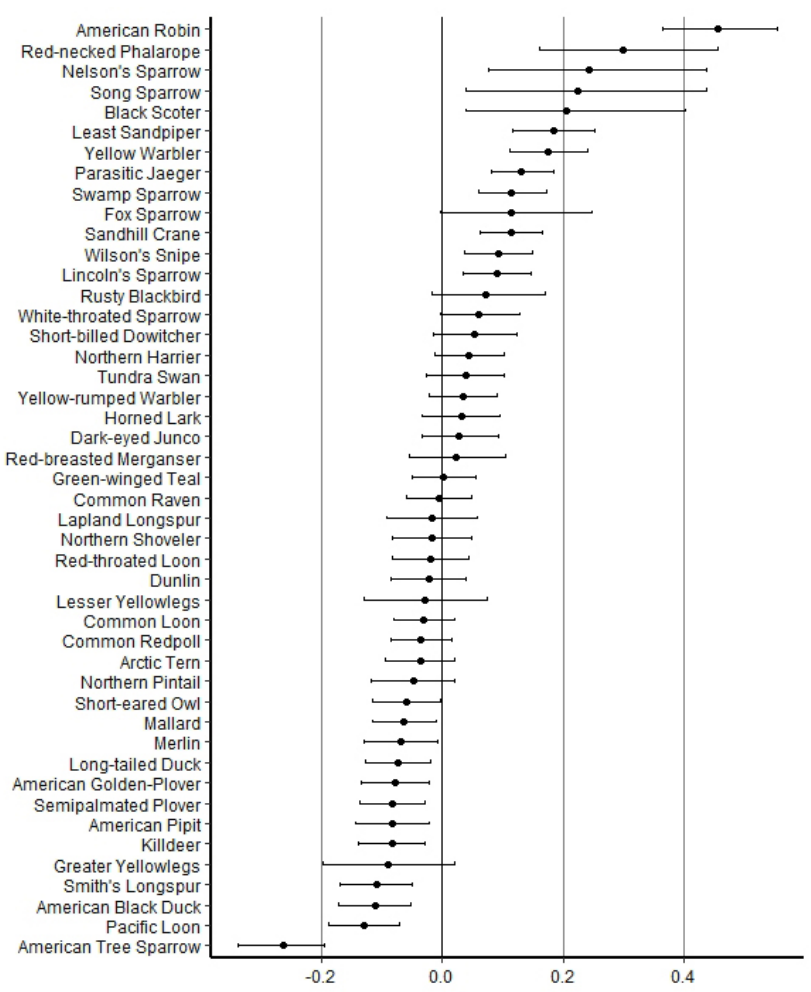

Fig. 3. A scatter plot of mean probability of observation (trends) and 95\% credible limits bars for comparing species observed at the Akimiski Island (1993 to 2015) and Burntpoint Creek (2001 to 2018, excluding 2006) study areas based on daily bird counts. The trend line represents the Pearson correlation (slope) between the sites.

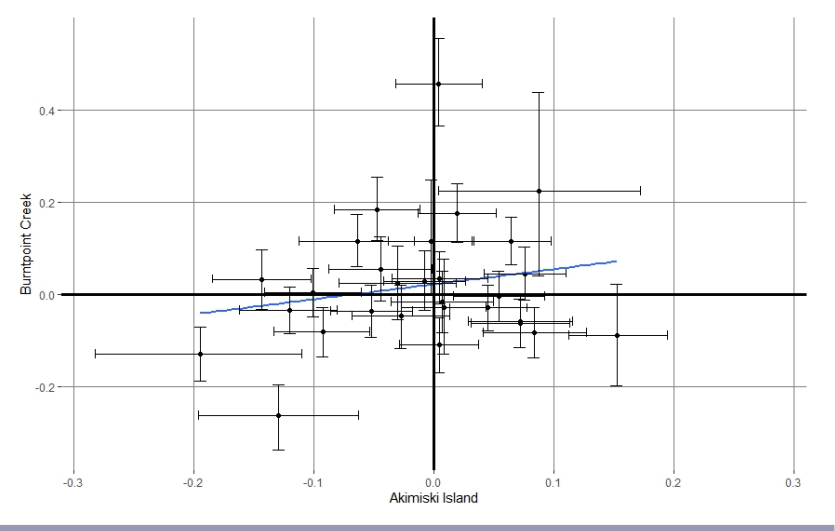


Avian Conservation and Ecology 16(1): 10

Table 2. Mean trends of the probability of observation (and 95\% credible limits) estimated from daily bird count data for species surveyed annually at the Burntpoint Creek study site in the sub-Arctic, 2001 to 2018 (excluding 2006). Trend comparisons are with those at the 1) regional scale; the Hudson Bay Lowlands (HBL) Breeding Bird Atlas trend from estimating the probability of observation between the first (1981 to 1985) and second (2001 to 2005) Atlases in Ontario, the 2) provincial scale using trends in abundance from the North American Breeding Bird Survey (2001 to 2018) and with the 3) Breeding Bird Survey at the national scale (2001 to 2018).

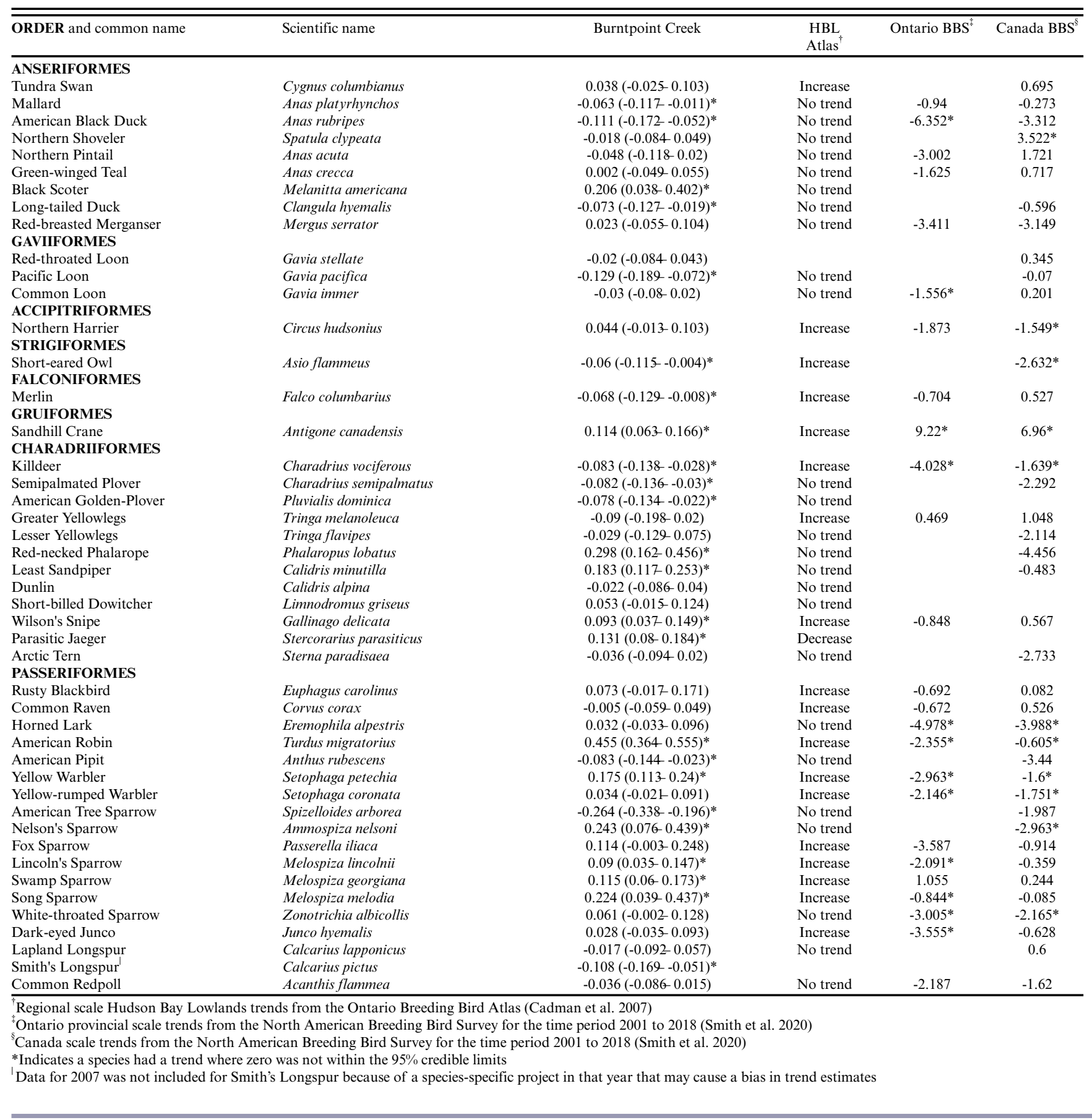

migratory species). The only geographic coverage overlap in data collection with our study sites was that for the regional scale; the Hudson Bay Lowlands (Cadman et al. 2007). Data collection at the provincial and national scales of the Breeding Bird Survey
(Smith et al. 2020) do not overlap geographically with our study area though we still made the trend comparisons because of species range overlap. Reasons for differences in trend direction that we observed may also include environmental or ecological 
Fig. 4. Scatter plots of the mean probability of observation (trend) and 95\% credible limits bars comparing species observed at the Akimiski Island study site (1993 to 2015) with trends in abundance from the A) Ontario Breeding Bird Survey and the C) national (Canada) Breeding Bird Survey. Similar comparisons were made for the mean probability of observation (trend) and 95\% credible limits bars comparing species observed at the Burntpoint Creek study site (2001 to 2018, excluding2006) with B) the Ontario Breeding Bird Survey trends and D) the Canada Breeding Survey trends for the same time period (2001 to 2018). Trend lines are Pearson correlation (slope).
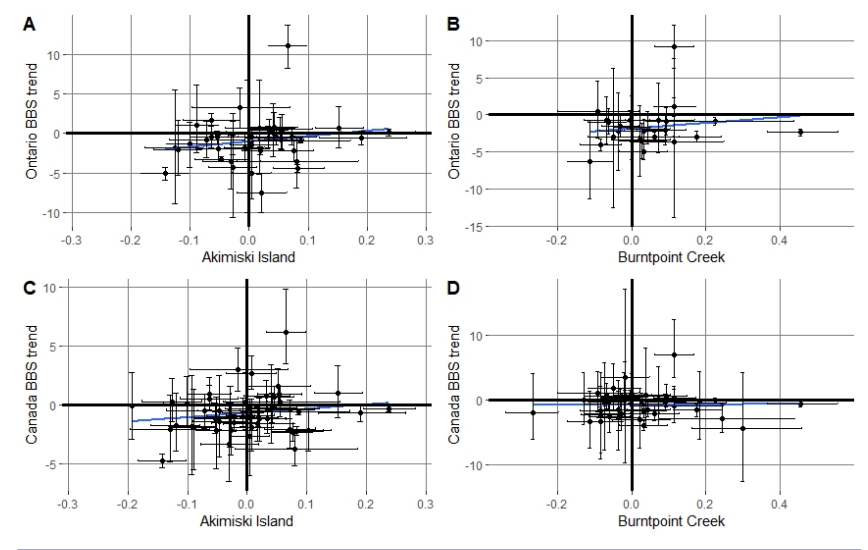

factors unique to sites near large waterfowl colonies (see below) which may cause local trends that might be undetectable at larger scales. Differences in trend direction observed between our study sites for five species found in common may be due to the negative ecological influence of the disproportionally larger densities of Lesser Snow and Canada Geese at the Akimiski Island site compared with lower densities of Canada Geese at the Burntpoint Creek site. Further, there may be an interaction with climate change processes that may be acting at different rates at the two sites. The Burntpoint Creek site is in low tundra habitat with continuous permafrost while the Akimiski Island site is in the boreal forest and is not influenced by permafrost.

We cannot offer definitive ecological explanations for trends observed because we have no observational or experimental evidence for causes as it was not the purpose of this research. However, we do offer two hypotheses (not necessarily competing) to help explain potential drivers and their mechanisms of influence on population change for the region encompassing our study areas: 1) relatively high densities of herbivores at our study sites (especially Akimiski Island) affects the habitat increasingly negatively and can indirectly affect predation rates of other bird species and their eggs/young (e.g., Abraham and Jefferies 1997, Flemming et al. 2016), and 2) climate change impacts both habitat and environmental conditions that could influence the breeding success of populations of birds in the sub-Arctic region at both sites (Wauchope 2017, Weiser et al. 2018b).

Herbivores may affect the abundance of bird populations in several ways. Herbivores may have enough impact on the vegetation that they consume that it could change important breeding vegetation structure used for nesting cover or feeding by other species (Rockwell et al. 2003, Peterson et al. 2013, Flemming et al. 2019). If sufficiently abundant, herbivores may also attract and maintain predator populations that could also target alternate prey or their eggs (Iles et al. 2013). This is a mechanism of concern where herbivores have become over-abundant (Lamarre et al. 2017) but it is not known what minimal densities herbivores must attain for other species to be affected. There is clear evidence that Canada Geese and Lesser Snow Geese at the Akimiski Island study site have had a detrimental impact on the plant community in coastal habitats mainly through the removal of biomass and creation of de-vegetated areas (Kotanen and Abraham 2013). The presence of geese and their eggs at these study sites also attract and maintain populations of predators (e. g., Arctic fox (Vulpes lagopus), Common Raven, American Crow, and Herring Gull (Larus argentatus)) that also prey on other bird species and their young (KFA personal communication). Continued or increasing effects of herbivory at these study sites may have an influence on the trends observed for some species. For example, we observed positive trends for American Crow and Common Raven abundance on Akimiski Island, which could be a result of their benefiting from availability of eggs and goslings of nesting geese. These two species in turn may cause a decline in some species whose eggs they also prey upon including those we predicted might have negative trends as a result. Of the duck species nesting at Akimiski Island, where we predicted negative trends, only the Northern Pintail trend was negative (low confidence). Trends for Mallard (high confidence) and American Black Duck (low confidence) were positive. In addition, other duck species where we could estimate trends including Greenwinged Teal and American Wigeon, had high confidence negative trends (Table 1). The duck species with negative trends were also in agreement with the low confidence negative trends observed at the provincial scale. We found a negative trend for all the shorebird species nesting on Akimiski Island where we made trend predictions (Semipalmated Plover, Least Sandpiper, and Shortbilled Dowitcher), However, none were covered well enough by the Breeding Bird Surveys to allow comparison of trend estimates at provincial and national scales and the trends estimated at the regional scale (atlas, HBL) were all low confidence. We did find that many of the open or grassland ground-nesting shorebird and waterfowl species showed negative trends at both study sites (Tables 1 and 2). Further study is needed to advance hypotheses regarding the direct and indirect influence of abundant herbivores.

Population trends of birds observed in Arctic and sub-Arctic regions could also be influenced by a changing climate through either climate-mediated change to habitat (e.g., Tape et al. 2006), development of a mismatch between nesting phenology and resource availability (e.g., Brook et al. 2015) or from changes in growing season length or other environmental conditions (Overpeck et al. 1997, Serreze et al 2000). These are not mutually exclusive hypotheses. The result may be a species breeding range expansion or contraction (La Sorte and Thompson 2007) that may appear as a significant trend at the local scale. With a poleward shift in species breeding distribution a possibility (Brommer 2004, Virkkala and Lehikoinen 2014), trends we observed for some species could be a consequence of climate change (e.g., longer suitable temperatures or growing seasons). 
Avian Conservation and Ecology 16(1): 10

http://www.ace-eco.org/vol16/iss1/art10/

Shrub expansion (Wheeler et al. 2018) in the Arctic and sub-Arctic regions is one consequence of a changing climate (Tape et al. 2006); increases in shrub cover, density, and height (Myers-Smith et al. 2011, Sturm et al. 2001) are some of the changes expected from a warming climate (Forbes et al. 2010) in this region. These changes are altering the proportions of vegetative cover and may favor the expansion of some bird species but be detrimental to others (Nguyen et al. 2003, Ballantyne and Nol 2011). Shrub encroachment is occurring at both study sites either through the spread of woody vegetation along tributaries toward Hudson Bay (at Burntpoint Creek) or from a contraction of the open graminoid habitats in the supratidal zone due to increasing woody vegetation as observed in the James Bay region including Akimiski Island (RWB, KFA unpublished data). The sparrow species for which we estimated an increasing trend could have benefitted from shrub expansion at both sites. At Burntpoint Creek, only Lincoln's and Song Sparrows showed an increasing trend which was consistent with the regional scale but was opposite the high confidence trend at the provincial scale. American Tree Sparrow indicated a negative trend which was consistent with that found at Akimiski Island but there were not any other high confidence trends estimated for other geographic scales. The White-throated Sparrow had a low confidence positive trend for Burntpoint Creek which was opposite the negative trends estimated at the provincial and national scales. For Akimiski Island, only the Song Sparrow indicated an increasing trend while we estimated declining trends for the Lincoln's and American Tree Sparrows. There was also a high confidence negative trend estimated for the Lincoln's Sparrow at the provincial scale. The evidence is not straight forward but our trend comparisons suggest that perhaps the local estimated positive trends for the Lincoln's, Song, and possibly also the White-throated Sparrows support the shrub encroachment hypothesis. These species also had trends opposite those estimated for at least one of the provincial or national scales. Targeted research is needed to more robustly explore potential drivers of the trends for these species at our study sites.

Using alternate sources of information on bird population trends may be even more important for species at risk or species of special concern, particularly where there is little information. Recovery strategies and legislated requirements emphasize the need for trend information for listed species to measure the success of recovery strategies. We reported a low confidence trend (positive but $95 \%$ credible limits overlapping 0) for the Rusty Blackbird (Euphagus carolinus) at Burntpoint Creek which is listed as a species of special concern, mainly due to population declines from the loss of wintering habitat (COSSARO 2017, COSEWIC 2017). The Rusty Blackbird population was considered stable between 2004 and 2014 in Canada (COSEWIC 2017) which overlapped the period that they were monitored at Burntpoint Creek (2001 to 2018). There was a positive highly confident trend at the regional scale but trends at the provincial and national scale were of low confidence.

The collection of bird list data can be done with minimal effort while collecting data for other projects. In comparison with other breeding bird surveys, it is not nearly as time consuming or as expensive. For regions where there is little or no other monitoring conducted for breeding birds, bird list analysis of time-series data can be a valuable method to estimate trends. These types of analyses may help fill a knowledge gap over a wide geographic area where accessibility is poor and there is scant other information.
Responses to this article can be read online at: https://www.ace-eco.org/issues/responses.php/1821

\section{Acknowledgments:}

We thank the staff at the Ontario Ministry of Natural Resources and Forestry and the many people who helped collect the data over many years. Thanks to Kim Bennett and Sarah Hagey for creating and maintaining the database. We thank the editor and two anonymous reviewers for comments that improved an earlier version of the manuscript. We are grateful to A. C. Smith for calculating period and region specific North American Breeding Bird Survey trends. Funding was provided by the Mississippiand Atlantic Flyway councils, Arctic Goose Joint Venture, Ontario Ministry of Natural Resources and Forestry, the Canadian Wildlife Service, Northern Scientific Training Program and Trent University.

\section{LITERATURE CITED}

Abraham, K. F., and R. L. Jefferies. 1997. High goose populations: causes, impacts, and implications. Pages 7-72 in B. D. J. Batt, editor. Arctic ecosystems in peril: report of the arctic goose habitat working group. Arctic goose joint venture special publication. United States Fish and Wildlife Service, Washington D. C. and Canadian Wildlife Service, Ottawa, Ontario, Canada.

ACIA. 2005. Arctic climate impact assessment. Cambridge: Cambridge University Press.

Ballantyne, K., and E. Nol. 2011. Nesting habitat selection and hatching success of Whimbrels near Churchill, Manitoba, Canada. Waterbirds 34:151-159. https://doi.org/10.1675/063.034.0203

Biuw M., J. U. Jepsen, J. Cohen, S. H. Ahonen, M. Tejesvi, S. Aikio, P. R. Wäli, O. P. L. Vindstad, A. Markkola, P. Niemelä, and R. A. Ims. 2014. Long-term impacts of contrasting management of large ungulates in the Arctic tundra-forest ecotone: ecosystem structure and climate feedback. Ecosystems 17:890-905. https://doi.org/10.1007/s10021-014-9767-3

Bonter, D. N., and C. B. Cooper. 2012. Data validation in citizen science: a case study from Project FeederWatch. Frontiers in Ecology and the Environment 10:305-307. http://dx.doi. org/10.1890/110273

Brommer, J. E. 2004. The range margins of northern birds shifts polewards. Annales Zoologici Fennici 41:391-397.

Brook, R. W., J. O. Leafloor, K. F. Abraham, and D. C. Douglas 2015. Density dependence and phenological mismatch: consequences for growth and survival of sub-arctic nesting Canada Geese. Avian Conservation and Ecology 10(1):1. http://dx. doi.org/10.5751/ACE-00708-100101

Buij, R., T. Melman, M. Loonen, and A. D. Fox. 2017. Balancing ecosystem function, services and disservices resulting from expanding goose populations. Ambio 46: 301-318. https://doi. org/10.1007/s13280-017-0902-1

Butler, R. W. 2000. Stormy seas for some North American songbirds: are declines related to severe storms during migration? Auk 117:518-522. https://doi.org/10.1093/auk/117.2.518 
Cadman, M. D., D. A. Sutherland, G. G. Beck, D. Lepage, and A. R. Couturier (eds.). 2007. Atlas of the breeding birds of Ontario, 2001 - 2005. Bird Studies Canada, Environment Canada, Ontario Field Ornithologists, Ontario Ministry of Natural Resources and Ontario Nature, Toronto, xxii +706 pp.

Callaghan, C. T., and D. E. Gawlik. 2015. Efficacy of eBird data as an aid in conservation planning and monitoring. Journal of Field Ornithology 86:298-304. http://dx.doi.org/10.1111/jofo.12121

COSSARO. 2017. Ontario species at risk evaluation report for Rusty Blackbird (Euphagus carolinus). Committee on the Status of Species at Risk in Ontario. [online] URL: http://cossaroagency. ca/wp-content/uploads/2018/06/Accessible_COSSARO_Evaluation_RustyBlackbird_FINAL_06FEB2018.pdf

COSEWIC. 2017. COSEWIC assessment and status report on the Rusty Blackbird Euphagus carolinus in Canada. Committee on the Status of Endangered Wildlife in Canada. Ottawa. xi +64 pp. [online] URL: http://www.registrelep-sararegistry.gc.ca/default. asp?lang=en \&n=24F7211B-1.

Crewe, T. L., J. D. McCracken, P. D. Taylor, D. Lepage, and A. E. Heagy. 2008. The Canadian migration monitoring network réseau canadien de surveillance des migrations: ten-year report on monitoring landbird population change. CMMN-RCSM Scientific Technical Report \#1. Produced by Bird Studies Canada, Port Rowan, Ontario, Canada.

Environment and Climate Change Canada. 2019. The Status of Birds in Canada Website, Data-version 2019. Environment and Climate Change Canada, Gatineau, Quebec, K1A 0H3) [online] URL: https://wildlife-species.canada.ca/bird-status/index-eng. aspx?sY=2019\&sL=e

Environment and Climate Change Canada. 2018. Evaluation of the migratory birds program. Environment Canada, Gatineau, Quebec, K1A 0H3 [online] URL: http://publications.gc.ca/ collections/collection_2018/eccc/En4-337-2018-eng.pdf

Fernández-i-Marín, X. 2020. Using the ggmcmc package version 1.5.0. [online] URL: https://cran.r-project.org/web/packages/ ggmcmc/vignettes/using_ggmcmc.html.

Flemming, S. A., A. Calvert, E. Nol, and P. A. Smith. 2016. Do hyperabundant Arctic-nesting geese pose a problem for sympatric species. Environmental Reviews 24:1-10. https://doi.org/10.1139/ er-2016-0007

Flemming, S. A., E. Nol, L. Kennedy, and P. A. Smith. 2019. Hyperabundant herbivores limit habitat availability and influence nest-site selection of Arctic-breeding birds. Journal of Applied Ecology 56: 976-987. doi: 10.1111/1365-2664.13336.

Forbes, B. C., M. M. Fauria, and P. Zetterberg. 2010. Russian Arctic warming and 'greening' are closely tracked by tundra shrub willows. Global Change Biology, 16, 1542-1554 https://doi. org/10.1111/j.1365-2486.2009.02047.x

Gelfand, A. E., and A. F. Smith. 1990. Sampling-based approaches to calculating marginal densities. Journal of the American Statistical Association 85:398-409. https://doi. org/10.1080/01621459.1990.10476213

Geweke, J. 1992. Evaluating the accuracy of sampling-based approaches to calculating posterior moments. In Bayesian
Statistics 4 (ed J. M. Bernado, J. O. Berger, A. P. Dawid and A. F. M. Smith). Clarendon Press, Oxford, UK.

Iles, D. T., R. F. Rockwell, P. Matulonis, G. J. Robertson, K. F. Abraham, C. Davies, and D. N. Koons. 2013. Predators, alternative prey, and climate influence annual breeding success of a long-lived sea duck. Journal of Animal Ecology 82:683-693. https://doi.org/10.1111/1365-2656.12038

Ims, R. A., J-A. Henden, M. A. Strømeng, A. V. Thingnes, M.J. Garmo, and J. U. Jepsen. Arctic greeming and bird nest predation risk across tundra ecotones. Nature Climate Change 9:607-610. https://doi.org/10.1038/s41558-019-0514-9

IPCC. 2018. Global warming of $1.5^{\circ} \mathrm{C}$ : An IPCC special report on the impacts of global warming of $1.5^{\circ} \mathrm{C}$ above pre-industrial levels and related global greenhouse gas emission pathways, in the context of strengthening the global response to the threat of climate change, sustainable development, and efforts to eradicate poverty, ed. V. Masson-Delmotte, P. Zhai, H. O. Pörtner, D. Roberts, J. Skea, P.R. Shukla, A. Pirani, W. Moufouma-Okia, C. Péan, R. Pidcock, S. Connors, J.B.R. Matthews, Y. Chen, X. Zhou, M.I. Gomis, E. Lonnoy, T. Maycock, M. Tignor, and T. Waterfield. In Press.

Kellner, K. 2018. jagsUI: a Wrapper Around 'rjags' to Streamline 'JAGS' Analyses, R package version 1.5.0. [online] URL: https:// cran.r-project.org/web/packages/jagsUI/index.html.

Kerbes, R. H., K. M. Meeres, and R. T. Alisauskas. 2014. Surveys of nesting lesser snow geese and Ross's geese in Arctic Canada, 2002-2009. Arctic goose joint venture special publication. U.S. Fish and Wildlife Service, Washington, D.C. and Canadian Wildlife Service, Ottawa, Ontario.

Kotanen, P. M., and K. F. Abraham. 2013. Decadal changes in vegetation of a subarctic salt marsh used by lesser snow and Canada geese. Plant Ecology 214:409-422. https://doi. org/10.1007/s11258-013-0178-X

Lamarre, J.-F., P. Legagneux, G. Gauthier, E. T. Reed, and J. Bêty. 2017. Predator-mediated negative effects of overabundant snow geese on arctic-nesting shorebirds. Ecosphere 8: e01788. 10.1002/ ecs2.1788 https://doi.org/10.1002/ecs2.1788

La Sorte, F. A., and F. R. Thompson. 2007. Poleward shifts in winter ranges of North American birds. Ecology 88:1803-1812. https://doi.org/10.1890/06-1072.1

Leafloor, J. O., K. F. Abraham, D. H. Rusch, R. K. Ross, and M. R. J. Hill. 1996. Status of the Southern James Bay population of Canada Geese. Pages 103-108 in J. T. Ratti, editor. Proceedings of the 7 th international waterfowl symposium. Memphis, Tennessee, USA.

Leafloor, J. O., M. R. J. Hill, D. H. Rusch, K. F. Abraham, and R. K. Ross. 2000. Nesting ecology and gosling survival of Canada geese on Akimiski Island, Nunavut. Towards conservation of the diversity of Canada Geese (Branta canadensis)(ed K. M. Dickson). pp 109-116. Canadian Wildlife Service Occasional Paper No. 103. Ottawa, Ontario.

Link, W. A., J. R. Sauer, and D. K. Niven. 2006. A hierarchical model for regional analysis of population change. Condor 108:13-24. https://doi.org/10.1093/condor/108.1.13 
Avian Conservation and Ecology 16(1): 10 http://www.ace-eco.org/vol16/iss1/art10/

McKinnon, L., M. Picotin, E. Bolduc, C. Juillet, and J. Bêty. 2012. Timing of breeding, peak food availability, and effects of mismatch on chick growth in birds nesting in the High Arctic. Canadian Journal of Zoology 90: 961-971. https://doi.org/10.1139/ z2012-064

Myers-Smith, I. H., B. C. Forbes, M. Wilmking, M. Hallinger, T. Lantz, D. Blok, K. D. Tape, M. Macias-Fauria, U. Sass-Klaassen, E. Lévesque, S. Boudreau, P. Ropars, L. Hermanutz, A. Trant, L. S. Collier, S. Weijers, J. Rozema, S. A. Rayback, N. M. Schmidt, G. Schaepman-Strub, S. Wipf, C. Rixen, C. B. Ménard, S. Venn, S. Goetz, L. Andreu-Hayles, S. Elmendorf, V. Ravolainen, J. Welker, P. Grogan, H. E. Epstein, and D. S. Hik. 2011. Shrub expansion in tundra ecosystems: Dynamics, impacts and research priorities. Environmental Research Letters 6, 045509 doi:10.1088/1748-9326/6/4/045509

Newbold, T., S. H. M. Butchart, Ç. H. Şekercioğlu, D. W. Purves, and J. P. W. Scharlemann. 2012. Mapping Functional Traits: Comparing Abundance and Presence-Absence Estimates at Large Spatial Scales. PLoS ONE 7: e44019. doi:10.1371/journal. pone.0044019

Nguyen, L. P., E. Nol, and K. F. Abraham. 2003. Nest success and habitat selection of the semipalmated plover on Akimiski Island, Nunavut. Wilson Bulletin 115:285-291. https://doi. org/10.1676/03-044

North American Bird Conservation Initiative Canada. 2019. The State of Canada's Birds, 2019. Environment and Climate Change Canada, Ottawa, Canada. 12 pages. www.stateofcanadasbirds. org.

Overpeck, J., K. Hughen, D. Hardy, R. Bradley, R. Case, M. Douglas, B. Finney, K. Gajewski, G. Jacoby, A. Jennings, S. Lamoureux, A. Lasca, G. MacDonald, J. Moore, M. Retelle, S. Smith, A. Wolfe, and G. Zielinski. 1997. Arctic environmental change of the last four centuries. Science 278: 1251-1256. https:// doi.org/10.1126/science.278.5341.1251

Peterson, S. L., R. F. Rockwell, C. R. Witte, and D. N. Koons. 2013. The legacy of destructive snow goose foraging on supratidal marsh habitat in the Hudson Bay Lowlands. Arctic, Antarctic, and Alpine Research 45:575-583. https://doi.org/10.1657/1938-4246.45.4.575

Plummer, M. 2013. JAGS: Just Another Gibbs Sampler. [online] URL: http://mcmc-jags.sourceforge.net/.

Pollock, L. A., K. F. Abraham, and E. Nol. 2012. Migrant shorebird use of Akimiski Island, Nunavut: a sub-arctic staging site. Polar Biology 35:1691-1701. https://doi.org/10.1007/ s00300-012-1211-6

Post, E. 2013. Erosion of community diversity and stability by herbivore removal under warming. Proceedings of the Royal Society B: Biological Sciences 280 (1757) https://doi.org/10.1098/ rspb.2012.2722

Post, E., M. C. Forchhammer, M. S. Bret-Harte, T. V. Callaghan, T. R. Christensen, B. Elderling, A. D. Fox, O. Gilg, D. S. Hik, T. T. Høye, R. A. Ims, E. Jeppesen, D. R. Klein, J. Madsen, A. D. McGuire, S. Rysgaard, D. E. Schindler, I. Stirling, M. P. Tamstorf, N. J. C. Tyler, R. van der Wal, J. Welker, P. A. Wookey, N. M. Schmidt, and P. Aastrup. 2019. Ecological dynamics across the
Arctic associated with recent climate change. Science 325: 1355-1358. https://doi.org/10.1126/science.1173113

R Development Core Team. 2018. R: a language and environment for statistical computing. R Foundation for Statistical Computing, Vienna, Austria.

Richards, S. A. 2007. Dealing with overdispersed count data in applied ecology. Journal of Applied Ecology 45:218-227. https:// doi.org/10.1111/j.1365-2664.2007.01377.x

Roach, J. K., B. Griffith, D. Verbyla, and J. Jones. 2011. Mechanisms influencing changes in lake area in Alaskan boreal forest. Global Change Biology 17: 2567-2583. https://doi. org/10.1111/j.1365-2486.2011.02446.x

Roberts, R. L., P. F. Donald, and R. E. Green. 2007. Using simple species lists to monitor trends in animal populations: new methods and a comparison with independent data. Animal Conservation 10:332-339. https://doi.org/10.1111/j.1469-1795.2007.00117. $\mathrm{x}$

Rockwell, R. F., C. R. Witte, R. L. Jefferies, and P. J. Weatherhead. 2003. Response of nesting savannah sparrows to 25 years of habitat change in a snow goose colony. Ecoscience 10:33-37. https://doi.org/10.1080/11956860.2003.11682747

Rosenberg, K. V., A. M. Dokter, P. J. Blancher, J. R. Sauer, A. D. Smith, P. A. Smith, J. C. Stanton, A. Panjabi, L. Helft, M. Parr, and P. P. Marra. 2019. Decline of the North American Avifauna. Science 10.1126/science.aaw1313. https://doi.org/10.1126/science. aaw1313

Ross, K. R., P. A. Smith, B. Campbell, C. A. Friis, and R. I. G. Morrison. 2012. Population trends of shorebirds in southern Ontario, 1974-2009. Waterbirds 35: 15-24. https://doi. org/10.1675/063.035.0102

Roy, C., N. L. Michel, C. M. Handel, S. L. Van Wilgenburg, J. C. Burkhalter, K. E. B. Gurney, D. J. Messmer, K. Princé, C. S. Rushing, J. F. Saracco, R. Schuster, A. C. Smith, P. A. Smith, P. Sólymos, L. A. Venier, and B. Zuckerberg. 2019. Monitoring boreal avian populations: how can we estimate trends and trajectories from noisy data? Avian Conservation and Ecology 14 (2):8. https://doi.org/10.5751/ace-01397-140208

Sauer, J. S., D. K. Niven, and W. A. Link. 2004. Statistical analyses make the Christmas Bird Count relevant for conservation. The 104th Christmas Bird Count. American Birds 58:21-25.

Sauer, J. R., W. A. Link, J. E. Fallon, K. L. Pardieck, and D. J. Ziolkowski Jr. 2013. The North American breeding bird survey 1966-2011: summary analysis and species accounts. North American Fauna 79:1-32. https://doi.org/10.3996/nafa.79.0001

Serreze, M. C., J. E. Walsh. F. S. Chapin III, T. Osterkamp, M. Dyurgerov, V. Romanovsky, W. C. Oechel, J. Morison, T. Zhang, and R. G. Barry. 2000. Observational evidence of recent change in the northern high-latitude environment. Climate Change 46:159-207. https://doi.org/10.1023/A:1005504031923

Smith, A. C., and B. P. M. Edwards. 2020. North American breeding bird survey status and trend estimates to inform a wide range of conservation needs, using a flexible Bayesian hierarchical generalized additive model. Ornithological Applications 123:1-16. https://doi.org/10.1101/2020.03.26.010215 
Smith, A. C., M-A. R. Hudson, V. I. Aponte, and C. M. Francis. 2020. North American Breeding Bird Survey - Canadian Trends Website, Data-version 2019. Environment and Climate Change Canada, Gatineau, Quebec, K1A 0H3.

Smith, P. A., L. McKinnon, H. Meltofte, R. B. Lanctot, A. D. Fox, J. O. Leafloor, M. Soloviev, A. Franke, K. Falk, M. Golovatin, V. Sokolov, A. Sokolov, and A. C. Smith. 2020. Status and trends of tundra birds across the circumpolar Arctic. Ambio. https://doi.org/10.1007/s13280-019-01308-5

Spiegelhalter D. J., N. G. Best, B. P. Carlin, and A. Van der Linde. 2002. Bayesian measures of model complexity and fit (with discussion). Journal of the Royal Statistical Society, Series B 64:583-616. https://doi.org/10.1111/1467-9868.00353

Studds, C. E., B. E. Kendall, N. J. Murray, H. B. Wilson, D. I. Rogers, R. S. Clemens, K. Gosbell, C. J. Hassell, R. Jessop, D. S. Melville, D. A. Milton, C. D. T. Minton, H. P. Possingham, A. C. Riegen, P. Straw, E. J. Woehler, and R. A. Fuller. 2017. Rapid population decline in migratory shorebirds relying on Yellow Sea tidal mudflats as stopover sites. Nature Communications 8: 14895. https://doi.org/10.1038/ncomms14895

Sturm, M., C. Racine, and K. Tape. 2001. Climate change: Increasing shrub abundance in the Arctic. Nature 411, 546-547. https://doi.org/10.1038/35079180

Szabo, J. K., P. A. Vesk, P. W. J. Baxter, and H. P. Possingham. 2010. Regional avian species declines estimated from volunteercollected long-term data using list length analysis. Ecological Applications 20:2157-2169. https://doi.org/10.1890/09-0877.1

Tape, K., M. Sturm, and C. Racine, C. 2006. The evidence for shrub expansion in Northern Alaska and the Pan-Arctic. Global Change Biology 12, 686-702. https://doi.org/10.1111/ j.1365-2486.2006.01128.x

Virkkala, R., and A. Lehikoinen. 2014. Patterns of climateinduced density shifts of species: poleward shifts faster in northern boreal birds than in southern birds. Global Change Biology 20: 2995-3003. https://doi.org/10.1111/gcb.12573

Walker, J. and P. D. Taylor. 2017. Using eBird data to model population change of migratory bird species. Avian Conservation and Ecology 12(1):4. https://doi.org/10.5751/ACE-00960-120104

Wauchope, H. S., J. D. Shaw, Ø. Varpe, E. G. Lappo, D. Boertmann, R. B. Lanctot, and R. A. Fuller. 2017. Rapid climatedriven loss of breeding habitat for Arctic migratory birds. Global Change Biology 23:1085-1094. https://doi.org/10.1111/gcb.13404

Weiser, E. L., S. Brown, R. B. Lanctot, H. R. Gates, K. F. Abraham, R. L. Bentzen, J. Bêty, M. L. Boldenow, R. W. Brook, T. F. Donnelly, W. B. English, S. A. Flemming, S. E. Franks, H. G. Gilchrist, M-A. Giroux, A. Johnson, S. Kendall, L. V. Kennedy, L. Koloski, E. Kwon, J-F. Lamarre, D. B. Lank, C. J. Latty, N.
Lecomte, J. R. Liebezeit, L. McKinnon, E. Nol, J. Perz, J. Rausch, M. Robards, S. T. Saalfeld, N. R. Senner, P. A. Smith, M. Soloviev, D. Solovyeva, D. H.Ward, P. F. Woodard, and B. K. Sandercock. 2018a. Effects of environmental conditions on reproductive effort and nest success of Arctic breeding shorebirds. Ibis 160: 608-23. https://doi.org/10.1111/ibi.12571

Weiser, E. L., S. C. Brown, R. B. Lanctot, H. R. Gates, K. F. Abraham, R. L. Bentzen, J. Bêty, M. L. Boldenow, R. W. Brook, T. F. Donnelly, W. B. English, S. A. Flemming, S. E. Franks, H. G. Gilchrist, M-A. Giroux, A. Johnson, L. V. Kennedy, L. Koloski, E. Kwon, J-F. Lamarre, D. B. Lank, N. Lecomte, J. R. Liebezeit, L. McKinnon, E. Nol, J. Perz, J. Rausch, M. Robards, S. T. Saalfeld, N. R. Senner, P. A. Smith, M. Soloviev, D. Solovyeva, D. H. Ward, P. F. Woodard, and B. K. Sandercock. 2018b. Life-history tradeoffs revealed by seasonal declines in reproductive traits of Arctic-breeding shorebirds. Journal of Avian Biology 49: https://doi.org/10.1111/jav.01531

Weiser, E. L., R. B. Lanctot, S. C. Brown, H. R. Gates, J. Bêty, M. L. Boldenow, R. W. Brook, G. S. Brown, W. B. English, S. A. Flemming, S. E. Franks, H. G. Gilchrist, M-A. Giroux, A. Johnson, S. Kendall, L. V. Kennedy, L. Koloski, E. Kwon, J-F. Lamarre, D. B. Lank, C. J. Latty, N. Lecomte, J. R. Liebezeit, R. L. McGuire, L. McKinnon, E. Nol, D. Payer, J. Perz, J. Rausch, M. Robards, S. T. Saalfeld, N. R. Senner, P. A. Smith, M. Soloviev, D. Solovyeva, D. H. Ward, P. F. Woodard, and B. K. Sandercock. 2020. Annual adult survival drives trends in Arctic-breeding shorebirds but knowledge gaps in other vital rates remain. The Condor. 122:1-14. https://doi.org/10.1093/condor/duaa026

Wheeler, H. C., T. T. Hoye, and J-C. Svenning. 2018. Wildlife species benefitting from a greener Arctic are most sensitive to shrub cover at leading range edges. Global Change Biology. https:// doi.org/10.1111/gcb.13837
Editor-in-Chief: Alexander L.Bond

Subject Editor: Erica Nol
Sponsored by the Society of Canadian Ornithologists and Birds Canada Parrainée par la Société des ornithologistes du Canada et Oiseaux Canada

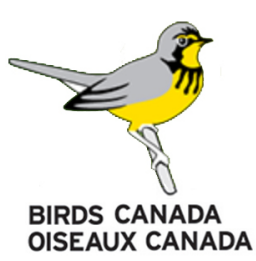

